\title{
Erratum to: MODERN TRENDS OF DEVELOPMENT OF ELECTRONIC TRADE IN THE CONDITIONS OF DIGITAL ECONOMY
}

\author{
Nataliya Tovma ${ }^{1 *}$, Kairzhan Kazbekova. ${ }^{\text {, Lubov Shamina }}{ }^{2}$, Kyz-Zhibek Abisheva ${ }^{\text {, }}$, Aigerim Nurgaliyeva ${ }^{l}$ \\ ${ }^{1}$ Al-Farabi Kazakh National University, al-Farabi Ave. 71, 050040 Almaty, Republic of Kazakhstan \\ ${ }^{2}$ Financial University under the Government of the Russian Federation, 197198, St. Petersburg, Russia
}

Original article:

E3S Web of conference

Volume 159, 2020

The $1^{\text {st }}$ International Conference on Business Technology for a Sustainable Environmental System (BTSES-2020) DOI: https://doi.org/10.1051/e3sconf/202015904022

The title of the article should be added author:

Lubov Shamina ${ }^{2}$

${ }^{2}$ Financial University under the Government of the Russian Federation, 197198, St. Petersburg, Russia 